\title{
Angiotensin Converting Enzyme Measurement
}

National Cancer Institute

\section{Source}

National Cancer Institute. Angiotensin Converting Enzyme Measurement. NCI

Thesaurus. Code C80169.

The determination of the amount of angiotensin converting enzyme present in a sample. 